\title{
A Study to Evaluate the Physicochemical Properties and Phytochemical Constituents of Five Aromatic Plants
}

\author{
Bhawana Srivastava $^{*}$, Priyanka Singh ${ }^{2}$, Anand Sagar ${ }^{1}$ and NK Dubey ${ }^{2}$ \\ ${ }^{\prime}$ Mycology \& Plant Pathology Laboratory, Department of Bio-Sciences, \\ Himachal Pradesh University, Shimla, India-171005 \\ ${ }^{2}$ Laboratory of Herbal Pesticide, Centre of Advanced Study in Botany \\ Banaras Hindu University, Varanasi, India -221005
}

\begin{abstract}
Aromatic plants are a tremendous source for the discovery of new products of medicinal value for drug development. Of late, several distinct chemicals derived from plants are important drugs. In the present investigation, alkaloid, saponin, steroid, phlobatannin, terpenoid, flavonoid, cardiac glycoside and phenol distribution were assessed and compared in five different aromatic plants belonging to two families.
\end{abstract}

Keywords: Alkaloid, Aromatic plants, Essential oils, Therapeutics

\section{Introduction}

Aromatic plants are major sources of natural products and used as pharmaceuticals, agrochemicals, flavor and fragrance ingredients, food additives, and pesticides. Some aromatic plants are of great importance to the health of individuals and communities. Plants have been used as traditional treatments for numerous human diseases for thousands of years. Many infectious diseases have been known to be treated with herbal remedies throughout the history of mankind. Natural products, either as pure compounds or as standardized plant extracts, provide unlimited opportunities for new drug leads because of the unmatched availability of chemical diversity. Today there is growing interest in chemical composition of plant based medicines. The medicinal value of these plants lies in some chemical substances that produce a definite physiological action on the human body. Several bioactive constituents have been isolated and studied for pharmacological activity. The most important of these bioactive constituents of plants are alkaloids, tannins, flavonoids, essential oils and phenolic compounds (1). The curative properties of plant made drugs are due to the presence of complex chemical substances of varied composition (present as secondary plant metabolites) in one or more parts of these plants. A medicinal herb is considered to be a chemical factory as it contains multitude of chemical compounds like alkaloids, glycosides, saponins, tannins, phlobatannins, flavonoids, steroids, essential oils and phenols.

A systematic search for useful bioactivities from plants is now considered to be a rational approach in nutraceutical and drug research. Therefore, the present work has been designed for phytochemical and physicochemical study of some aromatic plants. An effort has been made here to quantify the percentage of crude phytochemical constituents present in these plants with a view to contributing to the search for beneficial uses of these plants. The plants viz; Aegle marmelos L. Corr., Cinnamomum camphora (L.) Presl., Cinnamomum tamala Fr. Nees., Citrus maxima Burm. and Citrus sinensis L. osbeck. are extensively used in herbal medicine throughout the world and are easily available to the

* Corresponding Author: Email: bhawana.bhu@gmail.com 
authors. Their various uses in traditional medicine and therapeutics are reviewed in Table-1. These points made the basis for selection of these plants.

Table 1: Ethnobotanical information of selected aromatic plant species

\begin{tabular}{|c|c|c|c|c|}
\hline Plant species & Family & $\begin{array}{l}\text { Common } \\
\text { name }\end{array}$ & Parts used & Therapeutic use \\
\hline $\begin{array}{l}\text { Aegle marmelos L. } \\
\text { Corr. }\end{array}$ & Rutaceae & Bael & $\begin{array}{l}\text { Roots, leaves \& } \\
\text { fruits }\end{array}$ & $\begin{array}{l}\text { In diarrhoea, dysentery; } \\
\text { cardiopalmus, expectorant }\end{array}$ \\
\hline $\begin{array}{l}\text { Cinnamomum } \\
\text { camphora (L.) Presl. }\end{array}$ & Lauraceae & Kapoor & $\begin{array}{l}\text { Roots, leaves \& } \\
\text { wood }\end{array}$ & $\begin{array}{l}\text { Cardiac, analeptic and } \\
\text { anodyne properties. Effective } \\
\text { for fever, colic, sore throat } \\
\text { and impotence. }\end{array}$ \\
\hline $\begin{array}{l}\text { Cinnamomum tamala } \\
\text { Fr.Nees. }\end{array}$ & Lauraceae & Tejpat & Leaves, bark & $\begin{array}{l}\text { Alexeteric, anthelmintic, } \\
\text { carminative \& tonic, in } \\
\text { diarrhoea, in hepatopathy and } \\
\text { splenopathy }\end{array}$ \\
\hline Citrus maxima Burm. & Rutaceae & Chakotara & $\begin{array}{l}\text { Leaves, bark } \\
\text { \&Fruits }\end{array}$ & $\begin{array}{l}\text { In nervous infections, } \\
\text { epilepsy and convulsive } \\
\text { cough, painful swelling and } \\
\text { ulcers }\end{array}$ \\
\hline $\begin{array}{l}\text { Citrus sinensis L. } \\
\text { Osbeck. }\end{array}$ & Rutaceae & Mausmi & $\begin{array}{l}\text { Leaves, bark } \\
\text { \&Fruits }\end{array}$ & $\begin{array}{l}\text { As purgative, in abdominal } \\
\text { pains, relapse postpartum } \\
\text { sickness }\end{array}$ \\
\hline
\end{tabular}

\section{Materials and Methods}

\section{Collection and identification of plant materials}

The plants viz; A. marmelos, C. camphora, C. tamala, C. maxima and C. sinensis were identified with the help of the Flora of BHU campus (2) and leaves of these plants were collected from the botanical garden, Banaras Hindu University, Varanasi, India.

Isolation of essential oils from plants and their standardization through physico-chemical properties These leaves were cut separately into small pieces with the help of scissors and mortar \& pestle after washing with sterilized distilled water. The volatile fraction i.e. essential oils were isolated through hydro distillation by Clevenger's apparatus. The isolated fractions of plant leaves exhibited two distinct layers- an upper oily layer and the lower aqueous layer. Both the layers were separated and the essential oils were stored in clear glass vials separately after removing water traces with the help of capillary tube and anhydrous sodium sulphate (3).

The oils were standardized through physico-chemical properties viz. specific gravity, specific rotation, refractive index, acid number, saponification value, ester value and solubility (4). To estimate the solubility of oils, one $\mathrm{ml}$ of the oils was introduced separately into a $10 \mathrm{ml}$ glass stoppered cylinder (calibrated to $0.1 \mathrm{ml}$ ). Different solvents were added to it drop by drop separately by shaking the cylinder after each addition. The volume of solvent used to obtain a clear solution was noted. The oils were completely miscible with acetone, absolute alcohol, 90 per cent alcohol, butanol, chloroform, ethyl acetate, hexane and methanol in 1:1 concentration. 
Phytochemical screening

The aqueous extract of each leaf sample was prepared by soaking $100 \mathrm{~g}$ of dried powdered samples in $200 \mathrm{ml}$ of distilled water for $12 \mathrm{~h}$. The extracts were filtered using Whatman filter paper No. 42 (125 $\mathrm{mm})$.

Chemical tests were carried out on the aqueous extract and on the powdered specimens using standard procedures to identify the constituents as described by (1), (5), (6) and (7).

\section{Test for tannins}

About $0.5 \mathrm{~g}$ of the dried powdered samples was boiled in $20 \mathrm{ml}$ of water in a test tube and then filtered. A few drops of $0.1 \%$ ferric chloride was added and observed for brownish green or a blue-black colouration.

\section{Test for phlobatannins}

Deposition of a red precipitate when an aqueous extract of each plant sample was boiled with $1 \%$ aqueous hydrochloric acid was taken as evidence for the presence of phlobatannins.

\section{Test for saponin}

About $2 \mathrm{~g}$ of the powdered sample was boiled in $20 \mathrm{ml}$ of distilled water in a water bath and filtered. $10 \mathrm{ml}$ of the filtrate was mixed with $5 \mathrm{ml}$ of distilled water and shaken vigorously for a stable persistent froth. The frothing was mixed with 3 drops of olive oil and shaken vigorously, then observed for the formation of emulsion.

Test for flavonoids

Presence of flavonoids in the plant sample was determined following (5) and (7).

Test for steroids

Two $\mathrm{ml}$ of acetic anhydride was added to $0.5 \mathrm{~g}$ ethanolic extract of each sample with $2 \mathrm{ml} \mathrm{H}_{2} \mathrm{SO}_{4}$. The colour changed from violet to blue or green in some samples indicating the presence of steroids.

\section{Test for terpenoids}

Presence of terpenoids was confirmed by Salkowski test.

Test for cardiac glycosides

Presence of cardiac glycosides was confirmed by Keller-Killani test.

\section{Quantitative determination of the chemical constituents}

Preparation of fat free sample

$2 \mathrm{~g}$ of the samples were defatted with $100 \mathrm{ml}$ of diethyl ether using a soxhlet apparatus for $2 \mathrm{~h}$.

Determination of total phenols by spectrophotometric method

The fat free sample was boiled with $50 \mathrm{ml}$ of ether for the extraction of the phenolic component for 15 min. $5 \mathrm{ml}$ of the extract was pipetted into a $50 \mathrm{ml}$ flask, then $10 \mathrm{ml}$ of distilled water was added. $2 \mathrm{ml}$ of ammonium hydroxide solution and $5 \mathrm{ml}$ of concentrated amyl alcohol were also added. The samples were made up to mark and left to react for $30 \mathrm{~min}$ for colour development. This was measured at 505 nm. 
Alkaloid determination

Alkaloid determination was done using Harborne method (7).

Tannin determination

Tannin determination was done following Van-Burden and Robinson method (8).

Saponin determination

Saponin determination was done following Obdoni and Ochuko method (9).

Flavonoid determination

Flavonoid determination was done following the method of Bohm and Kocipai-Abyazan (10).

\section{Results \& Discussion}

The present study carried out on the plant samples revealed the presence of medicinally active constituents. The physicochemical and phytochemical characters of the five aromatic plants investigated are summarized in Tables- 2 and 3 respectively.

Table 2: Physicochemical properties of essential oils of selected aromatic plant species

\begin{tabular}{|c|c|c|c|c|c|}
\hline Parameters & A. marmelos & C. camphora & C. tamala & C. maxima & C. sinensis \\
\hline Colour & Yellow & White & Yellow & Light Yellow & Cream \\
\hline Odour & Sweet & Sweet & Pungent & Citrus like & Sweet \\
\hline \multicolumn{6}{|l|}{ Solubility } \\
\hline Acetone & Soluble (1:1) & Soluble (1:1) & Soluble (1:1) & Soluble (1:1) & Soluble (1:1) \\
\hline Absolute alcohol & Soluble (1:1) & Soluble (1:1) & Soluble (1:1) & Soluble (1:1) & Soluble (1:1) \\
\hline $90 \%$ alcohol & Soluble (1:1) & Soluble (1:1) & Soluble (1:1) & Soluble (1:1) & Soluble (1:1) \\
\hline Butanol & Soluble $(1: 1)$ & Soluble (1:1) & Soluble $(1: 1)$ & Soluble $(1: 1)$ & Soluble (1:1) \\
\hline Chloroform & Soluble (1:1) & Soluble (1:1) & Soluble $(1: 1)$ & Soluble $(1: 1)$ & Soluble (1:1) \\
\hline Ethyl acetate & Soluble (1:1) & Soluble (1:1) & Soluble (1:1) & Soluble (1:1) & Soluble (1:1) \\
\hline Hexane & Soluble $(1: 1)$ & Soluble (1:1) & Soluble (1:1) & Soluble $(1: 1)$ & Soluble (1:1) \\
\hline Methanol & Soluble (1:1) & Soluble (1:1) & Soluble (1:1) & Soluble (1:1) & Soluble (1:1) \\
\hline Refractive index & 1.48551 & 1.50058 & 1.39620 & 1.36130 & 1.47253 \\
\hline Specific gravity & 0.902443 & 0.90150 & 0.959210 & 0.971193 & 0.842575 \\
\hline Acid number & 0.65893 & 1.1 & 5.6 & 16.83 & 18.14 \\
\hline Saponification value & 185.4042 & 3.60000 & 21.03750 & 150.0675 & 197.0237 \\
\hline Ester value & 184.7453 & 2.50012 & 15.43750 & 133.2375 & 178.8837 \\
\hline
\end{tabular}

Table 3: Qualitative analysis of the phytochemicals of the medicinal plants

\begin{tabular}{|c|c|c|c|c|c|c|c|c|}
\hline Plants & Alkaloids & Saponin & Steriods & Phlobatannins & Terpenoids & Flavonoids & $\begin{array}{l}\text { Cardiac } \\
\text { glycosides }\end{array}$ & Phenols \\
\hline A. marmelos & + & + & + & - & + & - & + & + \\
\hline C. camphora & + & + & + & - & - & + & + & + \\
\hline C. tamala & + & + & + & - & + & + & + & + \\
\hline C. maxima & + & + & - & - & - & + & + & - \\
\hline C. sinensis & + & + & - & - & + & + & + & + \\
\hline
\end{tabular}


Quantitative estimation of the percentage crude chemical constituents studied in these aromatic plants is summarized in Table 4.

Table 4: Percentage of crude alkaloids, phenols, tannin, flavonoids, and saponin in aromatic plants investigated

\begin{tabular}{llllll}
\hline Plants & Alkaloids (\%) & Phenol (\%) & Tannin (\%) & Flavonoids (\%) & Saponin (\%) \\
\hline A. marmelos & $0.85 \pm 0.06$ & $0.22 \pm 0.02$ & $8.30 \pm 0.80$ & 0.00 & $2.30 \pm 0.20$ \\
C. camphora & $1.16 \pm 0.03$ & $0.18 \pm 0.01$ & $13.31 \pm 0.94$ & $1.67 \pm 0.02$ & $1.76 \pm 0.01$ \\
C. tamala & $0.94 \pm 0.01$ & $0.13 \pm 0.23$ & $11.31 \pm 0.27$ & $0.72 \pm 0.04$ & $1.86 \pm 0.06$ \\
C. maxima & $0.76 \pm 0.01$ & 0.00 & $13.65 \pm 0.78$ & $0.76 \pm 0.03$ & $2.07 \pm 0.04$ \\
C. sinensis & $0.78 \pm 0.02$ & $0.27 \pm 0.00$ & $12.00 \pm 0.00$ & $0.57 \pm 0.02$ & $3.92 \pm 0.11$ \\
\hline
\end{tabular}

The phytochemical screening and quantitative estimation of the percentage crude yields of chemical constituents of the plants studied showed that the leaves were rich in alkaloids, flavonoids, phenolics, tannins and saponins. Alkaloids, saponins and cardiac glycosides were found to be present in all the plants. It has been found that some of these investigated plants contained steroidal compounds. It should be noted that steroidal compounds are of importance and interest in pharmacy due to their relationship with such compounds as sex hormones (11).

The plants studied here can be seen as a potential source of useful drugs. Further studies are going on these plants in order to isolate, identify, characterize and elucidate the structure of the bioactive compounds. The antimicrobial activities of these plants for the treatments of the diseases as claimed by traditional healers are also being investigated.

\section{Acknowledgments}

The authors are thankful to University Grants Commission, New Delhi for providing financial assistance in the form of Dr. D. S. Kothari postdoctoral fellowship.

\section{References}

1. Edeoga, H.O., Okwu, D.E. and Mbaebie, B.O. (2005). Phytochemical constituents of some Nigerian medicinal Plants. African J. Biotechnol. 4(7): 685-688.

2. Dubey, N.K. (2004). Flora of BHU Campus. BHU Press, Varanasi, India.

3. Srivastava, B., Singh, P., Shukla, R. and Dubey, N.K. (2008). A novel combination of the essential oils of Cinnamomum camphora and Alpinia galanga in checking aflatoxin $\mathrm{B}_{1}$ production by a toxigenic strain of Aspergillus flavus. World J. Microbiol. Biotechnol. 24: 693697.

4. Tripathi, P., Dubey, N.K., Banergi, R. and Chansuria, J.P.N. (2004). Evaluation of some essential oils as botanical fungitoxicants in management of post-harvest rotting of Citrus fruits. World J. Microbiol. Biotechnol. 20:317-321.

5. Sofowara, A. (1993). Medicinal plants and Traditional medicine in Africa. Spectrum Books Ltd, Ibadan, Nigeria. pp. 289.

6. Trease, G.E. and W.C. Evans, 1989. Pharmacognosy. 11th Edn. Brailliar Tiridel and Macmillian Publishers, London.

7. Harborne, J.B. (1973). Phytochemical methods, London. Chapman and Hall, Ltd. pp. 149-188.

8. Van-Burden, T.P. and Robinson, W.C. (1981). Formation of complexes between protein and Tannin acid. J. Agric. Food Chem. 1:77. 
9. Obdoni, B.O. and Ochuko, P.O. (2001). Phytochemical studies and comparative efficacy of the crude extracts of some Homostatic plants in Edo and Delta States of Nigeria. Global J. Pure Appl. Sci. 8: 203-208.

10. Bohm, B.A. and Kocipai-Abyazan, R. (1994). Flavonoids and condensed tannins from leaves of Hawaiian Vaccinium vaticulatum and V. calycinium. Pacific Sci. 48: 458-463.

11. Okwu, D.E. (2001). Evaluation of the chemical composition of indigenous spices and flavouring Agents. Global J. Pure Appl. Sci. 7(3): 455-459. 